\title{
Recent changes in distribution pattern of freshwater crayfish in Croatia - threats and perspectives
}

\author{
Ivana Maguire $^{1, *}$, Göran Klobučar ${ }^{1}$, Krešimir $\breve{Z g a n e c}^{2}$, Mišel Jelić ${ }^{1}$, Andreja Lucić ${ }^{1}$ and \\ Sandra Hudina ${ }^{1}$ \\ ${ }^{1}$ University of Zagreb, Faculty of Science, Department of Biology, Rooseveltov trg 6, Zagreb, Croatia \\ ${ }^{2}$ University of Zadar, Department of Teacher Education Studies in Gospić, Gospić, Croatia
}

\begin{abstract}
Analysis of Croatian freshwater crayfish populations, aiming to gather new distributional data and complement previous surveys (2005-2011), was performed during 2014-2016, within the frame of Natura 2000 Integration Project. The research included different waterbodies across the whole of Croatia, harbouring both indigenous and non-indigenous crayfish species (ICS and NICS, respectively). Field work was conducted in 117 grid squares with dimensions $10 \times 10 \mathrm{~km}$, and up to four waterbodies were surveyed per grid square, making a total of 450 studied sites. Out of those, crayfish were not recorded in 368 sites. In the sites with crayfish presence (i.e., 82), the most frequently observed ICS was Astacus astacus (registered in 33 sites) followed by Austropotamobius pallipes (16 sites), Austropotamobius torrentium (12 sites), and Astacus leptodactylus (5 sites). Concerning NICS, the majority of records were for Orconectes limosus (13 sites), followed by Pacifastacus leniusculus (2 sites), whereas Procambarus fallax $\mathrm{f}$. virginalis was registered in only one locality. Comparisons of obtained data with those from previous surveys showed that NICS are progressively spreading and displacing ICS, as recorded for A. leptodactylus that was almost completely displaced by $O$. limosus in waterbodies of the east Croatia. Existing ICS populations are under growing anthropogenic preassure, frequently fragmented and isolated. Moreover, this survey showed that in the last decade $55 \%$ of A. astacus and $67 \%$ of A. pallipes populations disappeared mainly as a consequence of anthropogenic influence onto their habitats. Further monitoring and conservation actions for ICS should be urgently applied to mitigate negative impacts of both NICS and anthropogenic influence.
\end{abstract}

Keywords: Noble crayfish / narrow-clawed crayfish / stone crayfish / white-clawed crayfish / non-indigenous crayfish species

\begin{abstract}
Résumé - Changements récents dans la carte de distribution des écrevisses d'eau douce en Croatie - menaces et perspectives. L'analyse des populations croates d'écrevisses d'eau douce, visant à recueillir de nouvelles données de répartition et à compléter les relevés précédents (2005-2011), a été réalisée au cours de la période 2014-2016, dans le cadre du projet d'intégration Natura 2000. La recherche a porté sur différents cours d'eau dans toute la Croatie, abritant des écrevisses indigènes et non indigènes (ICS et NICS, respectivement). Le travail sur le terrain a été effectué dans un quadrillage de 117 quadrats de dimensions $10 \times 10 \mathrm{~km}$, et jusqu' à quatre plans d'eau ont été étudiés par quadrat, ce qui fait un total de 450 sites étudiés. Parmi ceux-ci, les écrevisses n'ont pas été recensées dans 368 sites. Dans les sites où il y avait des écrevisses (c. -à-d. 82), l'ICS le plus fréquemment observé était Astacus astacus (enregistré dans 33 sites), suivi de Austropotamobius pallipes (16 sites), Austropotamobius torrentium (12 sites) et Astacus leptodactylus (5 sites). En ce qui concerne le NICS, la majorité des signalements concernaient Orconectes limosus (13 sites), suivi de Pacifastacus leniusculus (2 sites), tandis que Procambarus fallax f. virginalis n' a été enregistrée que dans une seule localité. Les comparaisons des données obtenues avec celles des enquêtes précédentes ont montré que les NICS se répandent et déplacent progressivement les ICS, comme cela a été enregistré pour $A$. leptodactylus qui a été presque complètement déplacé par $O$. limosus dans les masses d'eau de l'est de la Croatie. Les populations actuelles d'ICS sont de plus en plus souvent exposées à une pression anthropique croissante, fragmentées et isolées. En outre, cette enquête a montré qu'au cours de la dernière décennie, $55 \%$ des populations d' A. astacus et $67 \%$ des populations d' A. pallipes ont disparu principalement
\end{abstract}

\footnotetext{
${ }^{*}$ Corresponding author: imaguire@biol.pmf.hr
} 
en raison de l'influence anthropique sur leurs habitats. D'autres mesures de surveillance et de conservation des ICS devraient être appliquées d'urgence pour atténuer les impacts négatifs des NICS et de l'influence anthropique.

Mots-clés : écrevisse à pattes rouges / écrevisse à pattes blanches / écrevisse des torrents / écrevisse à pattes grêles / écrevisses non indigènes

\section{Introduction}

Freshwater crayfish are known to play an important role in freshwater habitats since they exhibit a strong influence on physical characteristics of the environment, as well as on the biological interactions within it (Crandall and Buhay, 2008; Kouba et al., 2014). Due to their role in ecosystems, along with their characteristics (among the largest invertebrates with a relatively long life span, omnivorous feeding and burrowing activities) they are considered keystone species (Füreder et al., 2006).

European freshwaters are inhabited by five indigenous crayfish species (ICS) belonging to the genera Astacus (3 species) and Austropotamobius (2 species), and their recent distributional data were presented in Kouba et al. (2014). Their original distribution patterns have changed throughout history, frequently this was due to human-mediated translocations as crayfishes were an important food source for human consumption and thus economically important species (Policar and Kozák, 2015; Jussila et al., 2016).

In the last 100 years, the number of ICS populations and their abundance across Europe has been decreasing owing to negative anthropogenic pressure upon their habitats (modifications, fragmentation, urbanisation, water pollution) and overfishing (Füreder et al., 2006; Holdich et al., 2009; Weinländer et al., 2014). Another major contributor to the observed declines is climate change - pronounced and prolonged droughts - which is impeding their survival in many European regions (DiéguezUribeondo, 2006; Maguire et al., 2011). However, the biggest threat to European ICS is non-indigenous invasive crayfish species (NICS) established in Europe. The NICS biological and ecological characteristics of adaptability, aggressiveness, high fecundity, etc. have severe, adverse impacts on ICS (Westman et al., 2002, Twardochleb et al., 2013) resulting them being ousted from their habitats (Füreder et al., 2006; Hudina et al., 2016). Furthermore, some NICS are latent carriers of the pathogen $A$. astaci, causative agent of crayfish plague, which is lethal for ICS (Edgerton et al., 2004; Souty-Grosset et al., 2006; Filipová et al., 2013; Kozák, 2015; Rezinciuc et al., 2015). Currently there are at least 10 NICS in Europe, of which Pacifastacus leniusculus, Orconectes limosus and Procambarus clarkia (old NICS) had been introduced into Europe before the 1980s and are now widely distributed (Holdich et al., 2009; Kouba et al., 2014).

Until 2003, Croatian freshwaters harboured only European ICS (Maguire and Gottstein-Matočec, 2004), but now 3 invasive NICS are present in Croatia; namely $O$. limosus, $P$. leniusculus (Maguire et al., 2011) and Procambarus fallax f. virginalis (Samardžić et al., 2014). The invasive spiny-cheek crayfish, $O$. limosus, was first recorded in eastern Croatia, at Kopački rit, in 2003 where it has spread naturally along the Danube River from Hungary (Maguire and Klobučar, 2003). In 2008 the signal crayfish, P. leniusculus, was recorded in the Mura River, where it has spread naturally from Slovenia (Maguire et al., 2008). Since that time, NICS continue to spread via natural or humanmediated ways along several Croatian rivers (Hudina et al., 2009; Samardžić et al., 2014). Moreover, a recent study by Hudina et al. (2017) showed that P. leniusculus, introduced illegally into the Korana River in 2012, has expanded its range 2.5 times in 5 years. Currently, the presence of NICS in Black Sea draining waterbodies has resulted in displacing ICS from their habitats and introducing crayfish plague (Hudina et al., 2009, 2017; Maguire et al., 2011, 2016).

From European ICS, Croatia harbours 4 species: Astacus astacus, Astacus leptodactylus, Austropotamobius torrentium and Austropotamobius pallipes (Maguire and GottsteinMatočec, 2004; Maguire et al., 2011). A. astacus is naturally distributed in the waterbodies of the Black Sea drainage, with a few recorded populations in the Adriatic Sea drainage; most probably of anthropogenic origin (Maguire and GottsteinMatočec, 2004). The former drainage also harbour populations of A. leptodactylus and A. torrentium, while A. leptodactylus inhabits low-land rivers, $A$. torrentium is distributed in smaller rivers and streams at higher altitudes. Moreover, $A$. torrentium is also naturally present in a few streams of the Adriatic Sea drainage (Maguire et al., 2011; Klobučar et al., 2013). The presence of $A$. pallipes is notably exclusive to the waterbodies draining into the Adriatic Sea (Maguire and GottsteinMatočec, 2004; Jelić et al., 2016).

According to the Croatian National Red List of freshwater crayfish, A. astacus and A. torrentium are vulnerable species, while $A$. pallipes is endangered (Gottstein et al., 2011). All three species are protected by the Croatian Law of Nature Protection (NN 80/13) and listed in IUCN Red List of Threatened Species (Edsman et al., 2010, Füreder et al., 2010a, Füreder et al., 2010b), in the Annex III of the Bern Convention, and in the Annex II (A. torrentium, A. pallipes), and Annex V (A. torrentium, A. pallipes, A. astacus) of the EU Habitat Directive. These regulations acknowledge that the listed species are of community interest and require the designation of special protected areas for their conservation, and "whose taking in the wild and exploitation may be subject to management measures".

The general aim of this study was to update the data of freshwater crayfish species distributions in Croatian freshwater ecosystems (Maguire et al., 2011), with new records collected during 2014-2016 within the framework of the Natura 2000 Integration Project (NIP). Previous distributional studies were focused on Natura 2000 crayfish species (A. torrentium and $A$. pallipes), whereas NIP included all ICS and NICS across Croatia, with a particular emphasis being placed on regions that were previously understudied or unstudied. Therefore, we expected new findings for both ICS and NICS in previously unstudied parts of Croatia. Furthermore, another goal was to evaluate present threats of established crayfish populations and their future chances of surviving and/or to explain their 
absence. To this end habitat conditions were registered at study sites at the moment of survey as an indicator of the current status of the crayfish species. Finally, the objective of this study was to compare previous distributional data (Maguire et al., 2011) with data collected through NIP to assess changes in distribution patterns of ICS and NICS in Croatia.

\section{Materials and methods}

Research was conducted from early spring 2014 to late autumn 2016, and designed to monitor indigenous and NICS in all types of waterbodies across Croatia. Sites were chosen on the basis of existing literature data and databases using GIS analysis. The following criteria were considered: recorded crayfish presence/absence (focus was put on previously uninvestigated sites), position relative to existing protected areas (previously un-investigated sites within protected areas were prioritized), access and presence of minefields (sites with difficult access, e.g., gorges and sites with unexploaded mines left after Homeland War, were excluded), representative waterbodies within each $10 \times 10 \mathrm{~km}$ grid square (where possible, all major types within a grid square were included) and distance from a settlement (sites within settlements were avoided). If preselected sampling sites proved inaccessible when visited due to changes in recent water course regulations, building projects, road restorations, etc., the most representative replacement sites were chosen during the field work according to expert judgement.

Field work was conducted in 117 grid squares $10 \times 10 \mathrm{~km}$, and within each a $100 \mathrm{~m}$ transect was surveyed in up to four waterbodies. Each year field surveys were conducted from spring until late autumn during crayfish activity peak, and individuals were caught by hands and/or baited LiNi crayfish traps (Westman et al., 1978) and/or hand-made baited traps (Maguire et al., 2002); all traps were left in the water overnight. On average, 5 traps were used per site and a hand search lasted approximately $30 \mathrm{~min}$. Record of each site contained its GPS coordinates, habitat type supported by photographs, and any observed threats according to the National Habitat Classification (NN 88/14). Localities/waterbodies with a heterogeneous habitat (consisting of differentsized cobbles, macrophytes, etc.), no visible traces of pollution, earthen banks, and a well developed riparian zone, well separated from settlements or intensive agriculture, were considered to be good quality crayfish habitats, while those in which anthropogenic activity was observed were considered altered.

All captured crayfish were identified to species and their sex was determined. Upon identification, crayfish were released at the point of capture, except for the invasive species which were removed from the waterbody.

The collected data were compiled, joined with previous data and processed with program Microsoft Excel 2010. Geographical presentation of crayfish distribution was produced in ArcGIS 10.3 program package.

\section{Results}

Our study investigated 450 sites in 117 grid squares which averaged 3.8 localities per grid square. When these sites were added to the 520 sites surveyed in previous astacological studies, records are now available for a total of 970 sites in Croatia. Of this number, 20 sites have been examined more than once, which has enabled comparisons of the distributional data to be made.

Out of 450 studied sites, crayfish were caught (positive sites) at $82(18.2 \%)$, while in $368(81.8 \%)$ no crayfish were found (negative sites) (Fig. 1). At 140 (38\%) of the negative sites there was no obvious observed reason to explain the absence of crayfish (e.g., intensive agriculture). However, in $224(61 \%)$ of negative sites some type of anthropogenic pressure (intensive agriculture, modification of habitat, urbanisation, pollution) was observed, while 4 sites (1\%) were $3-12 \mathrm{~km}$ away from NICS populations.

During the survey, 4 native European crayfish species were confirmed present: A. astacus, A. leptodactylus, $A$. pallipes, $A$. torrentium, as well as 3 non-native invasive species: P. leniusculus, O. limosus and P. fallax f. virginalis. From the distributional data collected, the Continental biogeographical region was shown to contain 3 ICS and 3 NICS, while Alpine and Mediterranean regions harboured only ICS (Fig. 2, Tab. 1).

During this survey, A. astacus (noble crayfish) was recorded in 33 out of 82 positive localities (40.24\%), mainly in waterbodies of the Black Sea drainage, at altitudes from $90 \mathrm{~m}$ a.s.l. (Continental biogeographical region) to $840 \mathrm{~m}$ a.s.1. (Alpine biogeographical region) (Fig. 3, Tab. 1). In 13 (39\%) of those 33 localities, habitat quality was assessed as good, while $20(61 \%)$ were observed to have some type of anthropogenic pressure (intensive agriculture, modification of habitat, urbanisation).

In previous studes, $A$. astacus was established in 95 sites (Fig. 3), and 11 of those overlapped with currently surveyed localities. Crayfish were still present in 5 of these sites, while absent in 6 where habitat modification was observed (two had extensive gravel extraction, two with intensive agriculture, and two had waterbody engineering projects). Also, during this survey we have recorded 22 new localities with $A$. astacus.

A. leptodactylus was encountered at 5 of the 82 positive localities $(6.09 \%)$, in waterbodies of the Black Sea drainage within the Continental biogeographical region, at altitudes ranging from 82 to $225 \mathrm{~m}$ a.s.l. (Fig. 4, Tab. 1). Two of these were new localities for $A$. leptodactylus, and three (60\%) were exposed to some type of anthropogenice pressure (intensive agriculture, modification of habitat, urbanisation), while the remaining two $(40 \%)$ were near recorded NICS sites. At one of these localities, $O$. limosus was in the same waterbody but about $200 \mathrm{~m}$ downstream, and in the other, P. leniusculus was found in the same river basin $26 \mathrm{~km}$ away. Furthermore, previous surveys recorded A. leptodactylus at 30 sites, of which 3 overlapped with the current investigation. At all 3 overlapping sites, A. leptodactylus was replaced by the invasive $O$. limosus. Previous astacological studies have indicated A. leptodactylus is spreading towards west and south of Croatia. During this survey, we have recorede its presence in the left tributary of the Sava River, which suggests that this crayfish is also spreading northwards.

The field survey showed that $A$. pallipes is present in 16 out of 82 positive localities (19.51\%), and all populations were recorded in the Adriatic Sea drainage, in the Alpine and Mediterranean biogeographical regions at altitudes from 985 


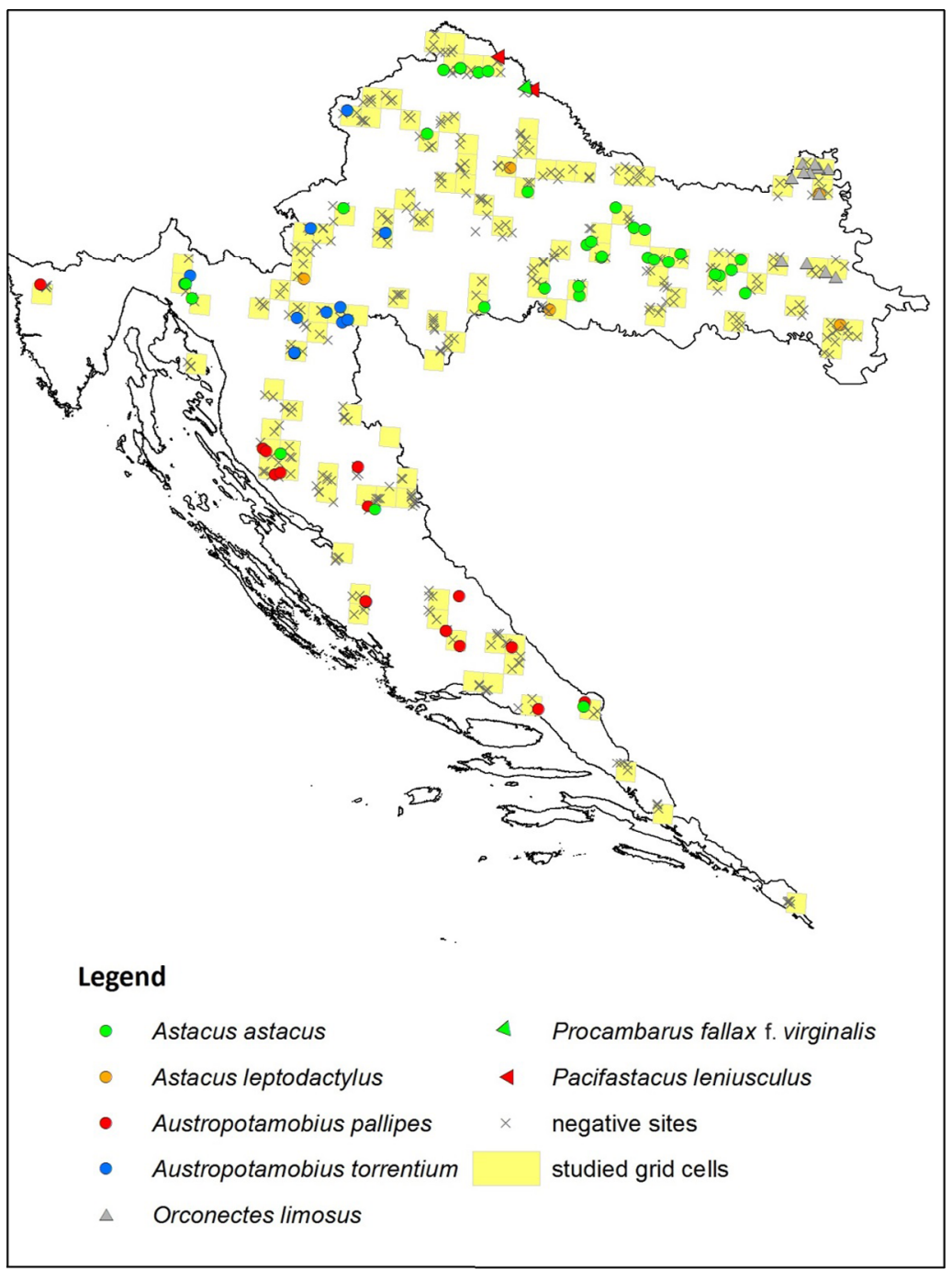

Fig. 1. Distribution pattern of ICS and NICS and negative sites in studied grid squares $10 \times 10 \mathrm{~km}$ established by present survey.

to $35 \mathrm{~m}$ a.s.1., respectively (Fig. 5, Tab. 1). At $10(62.5 \%)$ of those sites good habitat conditions were observed, while the remaining 6 sites $(37.5 \%)$ had waterbody engineering or intensive agriculture activity in their vicinity. Previously $A$. pallipes was collected from 59 localities, 6 which were included in the current suvey. However, only 2 of these sites still support crayfish, while in 4 sites crayfish were not found (in 2 sites intensive agriculture and in 2 dry riverbed was observed). Our survey recorded 10 new localities with $A$. pallipes. Populations that showed a good status and high abundance, at the moment of survey, were present in hardly accessible, frequently isolated sites, and probably represent the remnants of previously widely distributed populations.

A. torrentium was established in 12 out of 82 positive localities, situated in smaller streams at higher altitudes in all three biogeographical regions in Croatia at altitudes from $154 \mathrm{~m}$ a.s.l. (Continental biogeographical region) to $1072 \mathrm{~m}$ a. s.1. (Alpine biogeographical region) (Fig. 6, Tab. 1). Of those 12 localities, 7 (58\%) had good habitat conditions, while 4 (34\%) were influenced by anthropogenic pressures (intensive agriculture, urbanisation), and in 1 (8\%) NICS were observed in the same river basin, $24 \mathrm{~km}$ away. There was no overlapping localities (Fig. 6) so all 12 sites in our study are new records for A. torrentium. As in the case of A. pallipes, the majority of registered populations were situated in isolated sites that are not easily accessible.

Non-native invasive crayfish consisted of $P$. leniusculus at $2(2.43 \%)$, and $O$. limosus in $13(15.85 \%)$ out of the 82 positive localities surveyed (Fig. 7, Tab. 1). The presence of $P$. leniusculus in the Mura and Drava rivers confirmed previous observations, while those of $O$. limosus in waterbodies in east Croatia indicated that this latter species has significantly expanded its range, compared to previous data ( 9 records); 13 new localities with its presence were registered. From newly established crayfish species we found $P$. fallax $\mathrm{f}$. virginalis in one gravel pit (1.22\%) (Fig. 7). Presence of this species was confirmed in 2014, while it was observed for the first time in 2013. Intense surveys in the waterbodies around the gravel pit during NIP survey did not establish its presence in the vicinity.

Collected data indicate that the waterbodies in the Continental biogeographical region are the most burdened with NICS, with majority of populations being recorded in the far east of Croatia (Fig. 7). 


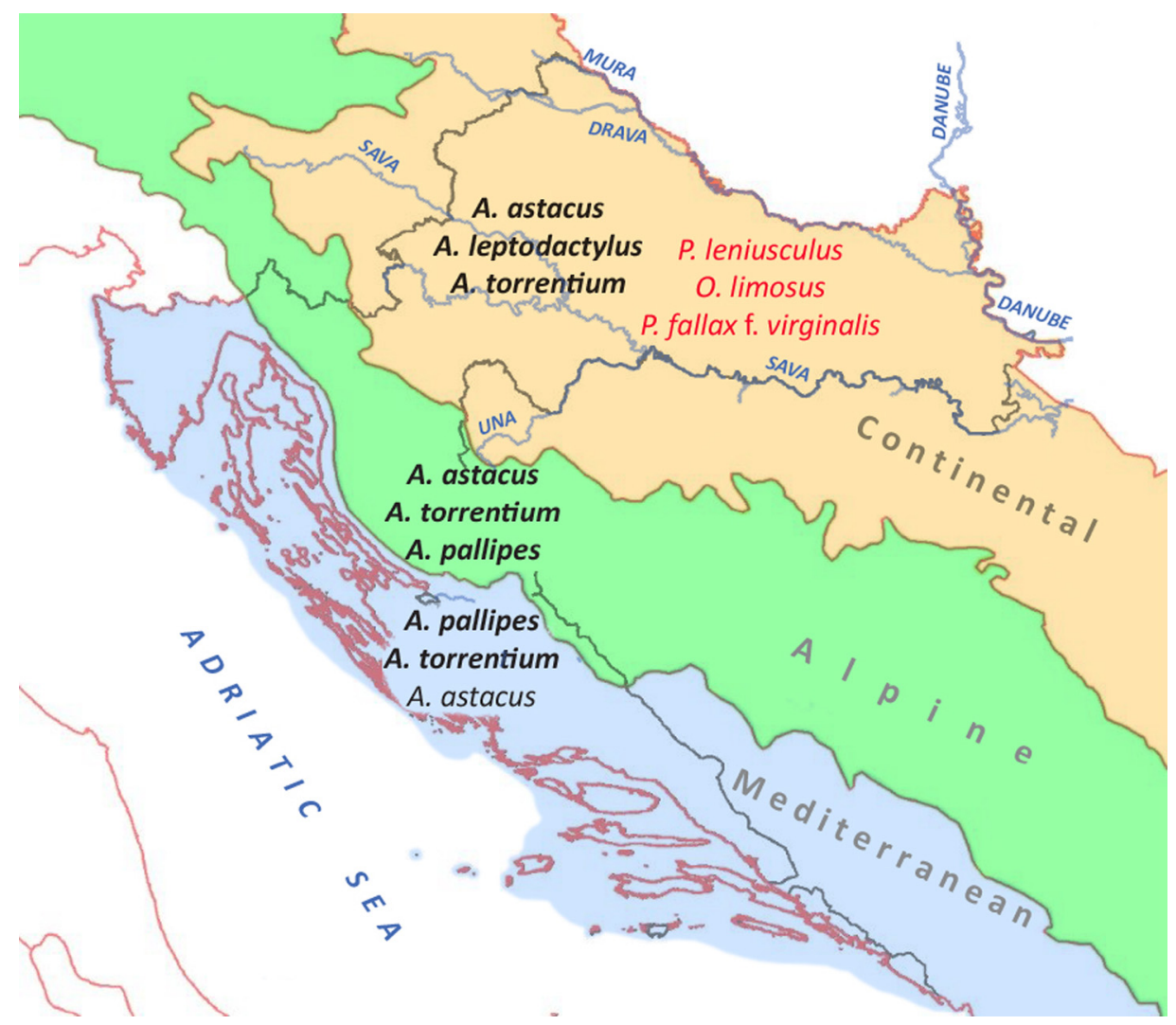

Fig. 2. Biogeographical regions (defined according to https://www.eea.europa.eu/data-and-maps/data/biogeographical-regions-europe-3) in Croatia with present ICS and NICS. ICS names are written in black colour (bold letters are used if species is native in the region). NICS names are written in red colour. Names of biogeographical regions are written in grey colour. Hydrographic network (only main waterbodies) are also included into the map and are presented in blue colour.

Table 1. Overview of ICS and NICS distribution in different biogeographical regions (defined according to https://www.eea.europa.eu/dataand-maps/data/biogeographical-regions-europe-3) during the current survey. Number of recorded population per species and region are given, as well as belonging to sea basin.

\begin{tabular}{llll}
\hline & & Biogoegraphic region & Mediterranean \\
\cline { 2 - 4 } Species/Sea basin & $\begin{array}{l}\text { Continental } \\
\text { Black Sea }\end{array}$ & $\begin{array}{l}\text { Alpine } \\
\text { Black Sea and Adriatic Sea }\end{array}$ & 1 \\
\hline Astacus astacus & 28 & 4 & 0 \\
Astacus leptodactylus & 5 & 0 & 10 \\
Austropotamobius pallipes & 0 & 6 & 0 \\
Austropotamobius torrentium & 8 & 4 & 0 \\
Pacifastacus leniusculus & 2 & 0 & 0 \\
Orconectes limosus & 13 & 0 & 0 \\
Procambarus fallax f. virginalis & 1 & 0 & 0 \\
\hline
\end{tabular}

\section{Discussion}

The results presented in this work supplement previously published data on the distribution of crayfish in Croatian freshwaters (Maguire and Gottstein-Matočec, 2004; Maguire et al., 2011), which now totals of 970 surveyed sites.
Many of studied grid squares (and localities within them) were not cover in previous astacological field studies due to the higher level of anthropogenic pressure, or the assumption that Natura 2000 species (i.e., A. pallipes and A. torrentium that were the focus of former surveys) are not present there (Maguire et al., 2011). Hence, such a high number of negative localities was expected, given that level of anthropogenic pressure is inversely proportional to crayfish presence 


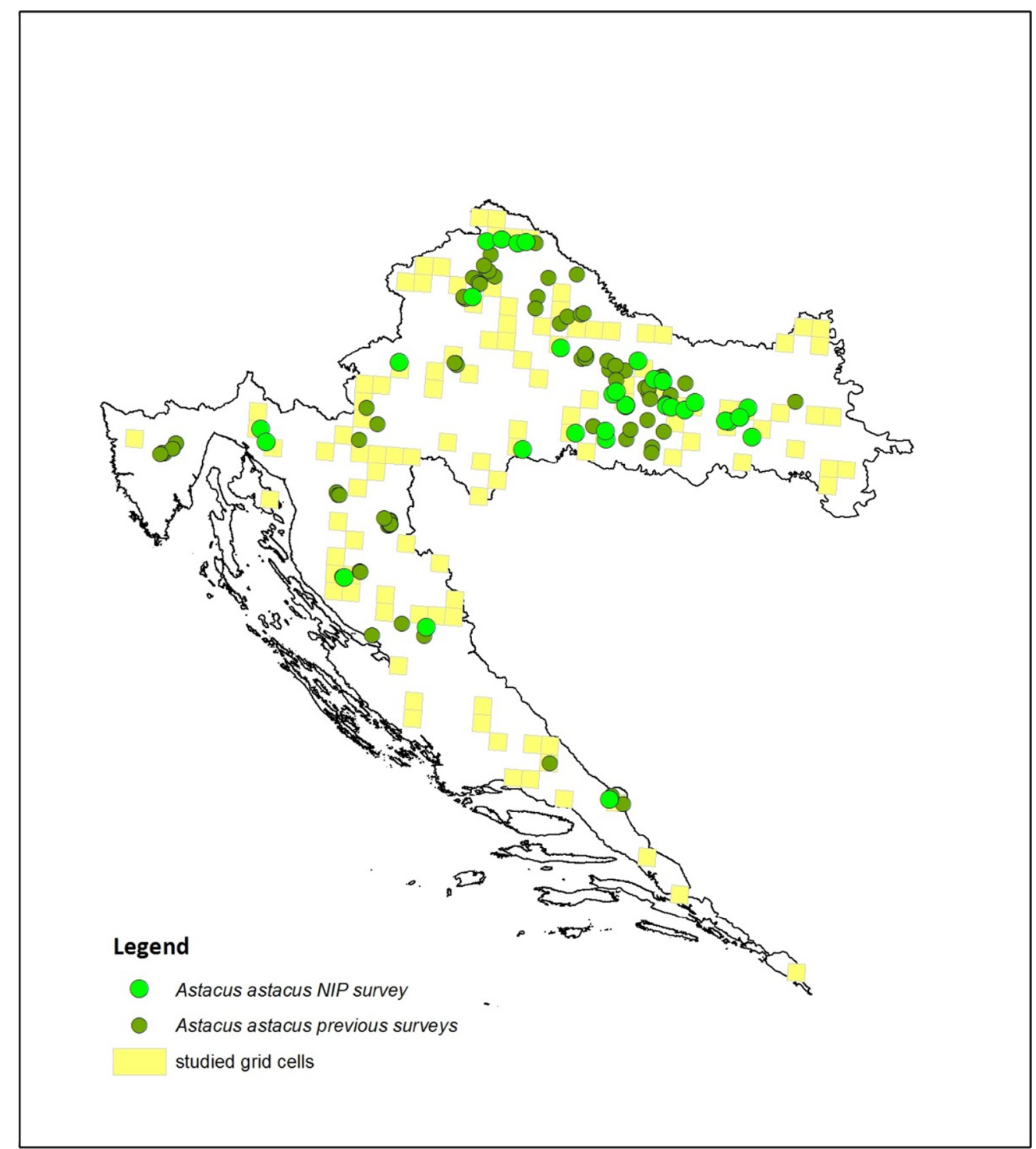

Fig. 3. Astacus astacus records within studied grid squares (light green dots) and records from previous studies (dark green dots).

(Fratini et al., 2005; Füreder et al., 2006; Weinländer et al., 2014; Chucholl and Schrimpf, 2016; Rosewarne et al., 2017). Indeed, in $61 \%$ of negative localities habitat conditions had been altered by intensive agriculture, waterbody engineering, direct municipal waste water influx, tourism, etc., while in $1 \%$, NICS, as potential crayfish plague vectors, were recorded. Still, in $38 \%$ of localities without crayfish records, no obvious threats to habitat were observed. Therefore, it is possible that in some of those localities crayfish populations do exist, but they were not detected due to their low abundance that hampered standard field effort approach applied during the survey. Also, it is possible that in some of the studied waterbodies crayfish are present, but in parts that were unreachable (heavily mined, canyons, etc.) or that were out of studied grid squares defined by the project.

Just 15 years ago, freshwaters in Croatia harboured only European ICS (Maguire and Gottstein-Matočec, 2004). Since the appearance of NICS in the country, either through natural dispersal (Maguire and Klobučar, 2003; Maguire et al., 2008) or illegal introductions (Hudina et al., 2013; Samardžić et al., 2014), their range expansion continues (this study, Hudina et al., 2017), and is consistant with findings across Europe (Kouba et al., 2014 and references therein).

It is especially alarming discovery of our survey, and Hudina et al. (2017), that A. leptodactylus has been completely displaced by the invasion of $P$. leniusculus in the Korana River. The catchment basin of this river harbours genetically and morphologically diverse populations of $A$. torrentium and A. astacus (Maguire et al., 2011, 2017; Klobučar et al., 2013), and if urgent measures for $P$. leniusculus eradication are not intensified soon, it is highly probable that local $A$. torrentium and $A$. astacus populations will become extinct.

Today, NICS comprise 3 out of 7 crayfish species present in Croatia, and since 2003, they have occupied numerous waterbodies within 30 out of $32710 \times 10 \mathrm{~km}$ grid squares of the Continental biogeographic region in Croatia. In at least two localities, they have displaced ICS over a 1-3 years period what is not surprising knowing their dispersal rate of $24 \mathrm{~km} /$ 


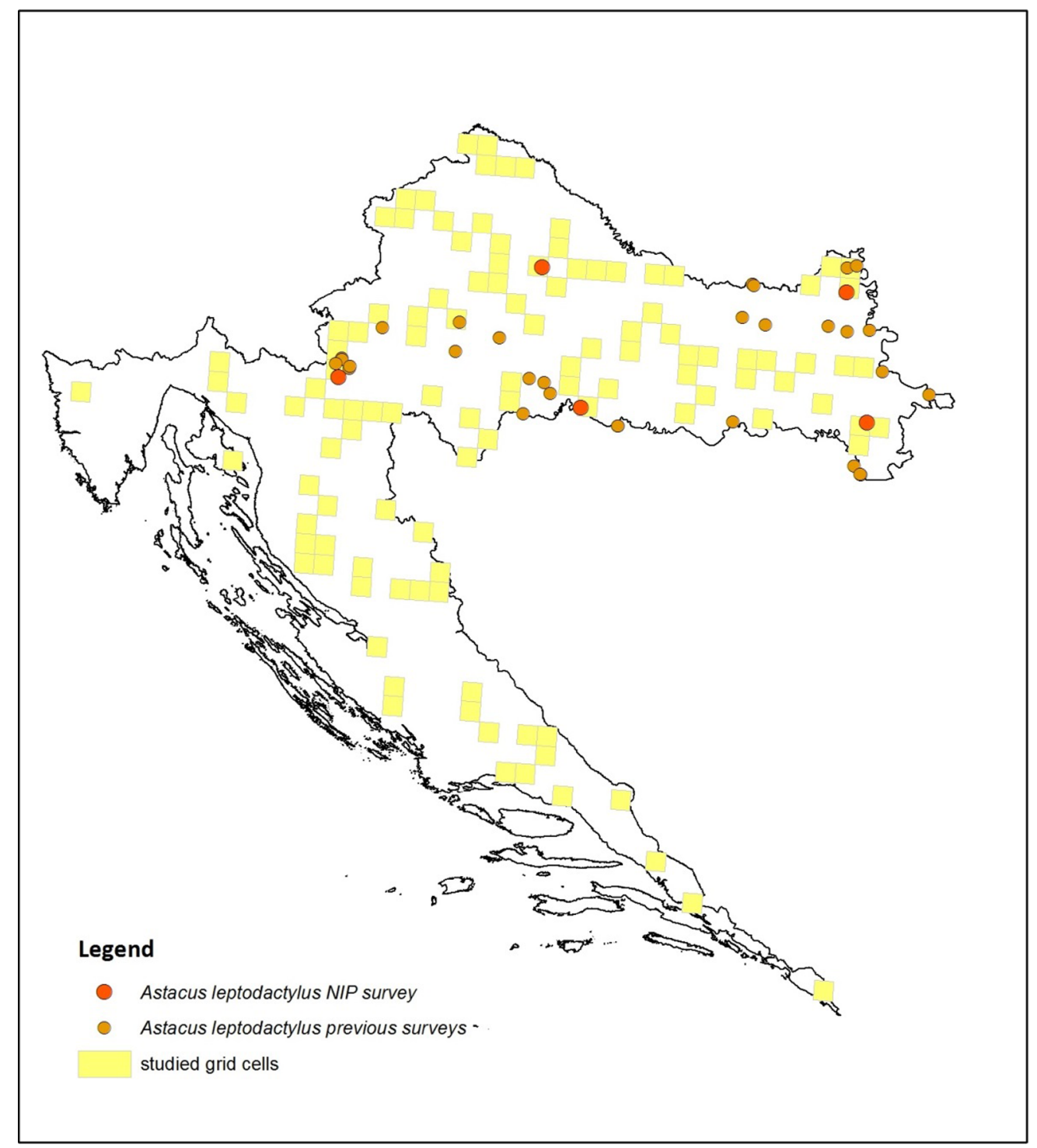

Fig. 4. Astacus leptodactylus records within the studied grid squares (orange dots) and records from previous studies (light brown dots).

year downstream, and $2.5 \mathrm{~km} /$ year upstream (Hudina et al., 2009, 2017). In areas where ICS and NICS have came into contact, transmission of $A$. astaci was recorded (Maguire et al., 2016). In addition, new NICS populations have been reported in neighbouring countires close to Croatia's border; with $O$. limosus in the Drava River in Slovenia (Govedič, 2017) and $P$. fallax $\mathrm{f}$. virginalis in the waterbodies of the Balaton region in Hungary (Ludányi et al., 2016); hence future, new invasive fronts are anticipated.

Even though management plans and actions for NICS eradication are under development by state institutions, and educational activities aiming to raise public awareness of the negative impacts NICS have on native biodiversity are carried out, no large scale, intense eradication programs have been initiated. Therefore there is every reason to predict further range expansion of NICS and consequent damage to waterbodies in the Continental Croatian region.

Croatian freshwaters harbour four out of five European ICS, and recent molecular-phylogenetic studies revealed high genetic diversity within three of them $-A$. astacus (Schrimpf et al., 2014), A. pallipes (Jelić et al., 2016) and A. torrentium (Klobučar et al., 2013). Such biodiversity requires special attention and knowledge of their distribution, amongst others, is essential if adequate conservation measures are to be applied (Souty-Grosset, 2005). The present survey demonstrated that localities harbouring abundant ICS populations are frequently isolated and hard to reach being situated in headwater areas of waterbodies that often show altered habitat conditions or presence of NICS further downstream. This trend has been already documented in many European countires, e.g., for $A$. torrentium (Bohl, 1999; Füreder et al., 2006; Chucholl and Schrimpf, 2016), A. pallipes (Füreder et al., 2002; Ghia et al., 2013), and A. astacus (Simić et al., 2008; Pârvulescu et al., 2011; Perdikaris and Georgiadis, 2017a). We may presume that these current isolated ICS populations represent the remnants of a more extensive distribution in the past (Entz, 1914; Karaman, 1929; Karaman, 1961; Maguire and GottsteinMatočec, 2004; Jussila et al., 2016). Such fragmented 


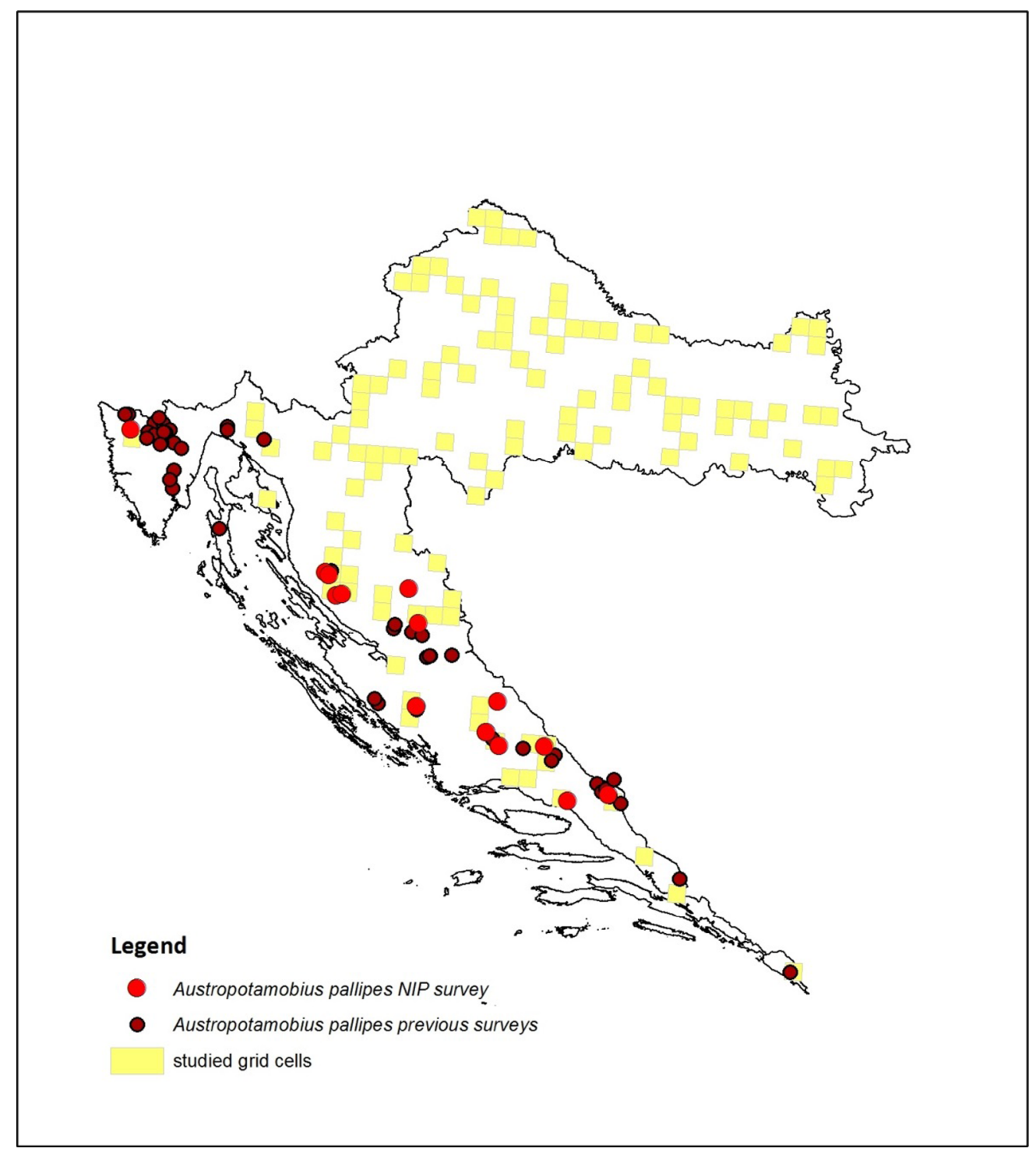

Fig. 5. Austropotamobius pallipes records within studied grid squares (red dots) and records from previous studies (brown dots).

populations, and their long-term sustainability may be threatened bearing in mind that loss of connectivity may lead to gene flow decrease and consequently genetic diversity reduction, and eventually population extinction (Keller and Waller 2002). Similar scenarios for different ICS have already been recorded in Europe (Grandjean et al., 2001; Gouin et al., 2002; Giesen, 2013; Chucholl and Schrimpf, 2016).

When comparing habitat quality (good vs. negatively altered) where crayfish were recorded during this survey, it was evident that $A$. pallipes and $A$. torrentium mainly inhabit environments with a good ecological status $(62.5 \%$ and $58 \%$ respectively) compared to those occupied by $A$. astacus (39\%). Since recorded anthropogenic pressures on $A$. astacus habitats are higher than those of $A$. pallipes and A. torrentium, it is expected that further increase of land-use around waterbodies harbouring $A$. astacus will result in additional losses (Chucholl and Schrimpf, 2016; Weinländer et al., 2014).

In general, most of $A$. astacus were found in smaller waterbodies (small rivers, streams), away of settlements, and frequently isolated. For the 6 populations found in gravel pits or impoundments, we believe that either $A$. astacus have been introduced from nearby rivers, or they were stranded in oxbows that were subsequently developed into gravel pits. Therefore, these populations represent the remnants of the river's original populations, e.g., gravel pits along the Drava River.

Furthermore, comparison of previous and current distributional data, in the overlapping localities, enables us to estimate that $55 \%$ of $A$. astacus and $67 \%$ of $A$. pallipes populations disappeared in the last decade, mainly due to anthropogenic influence onto their habitats. The recorded alarming trend of $A$. pallipes disappearance from the waterbodies of the Adriatic Sea drainage is similar to $68 \%$ disappearance previously reported (Maguire et al., 2011), and consistent with records from other European countries (Gil-Sánchez and AlbaTercedor, 2006; Holdich et al., 2009). The most probable reason for their disappearance is a reduction in water levels, due to droughts or excessive water abstraction for agricultural 


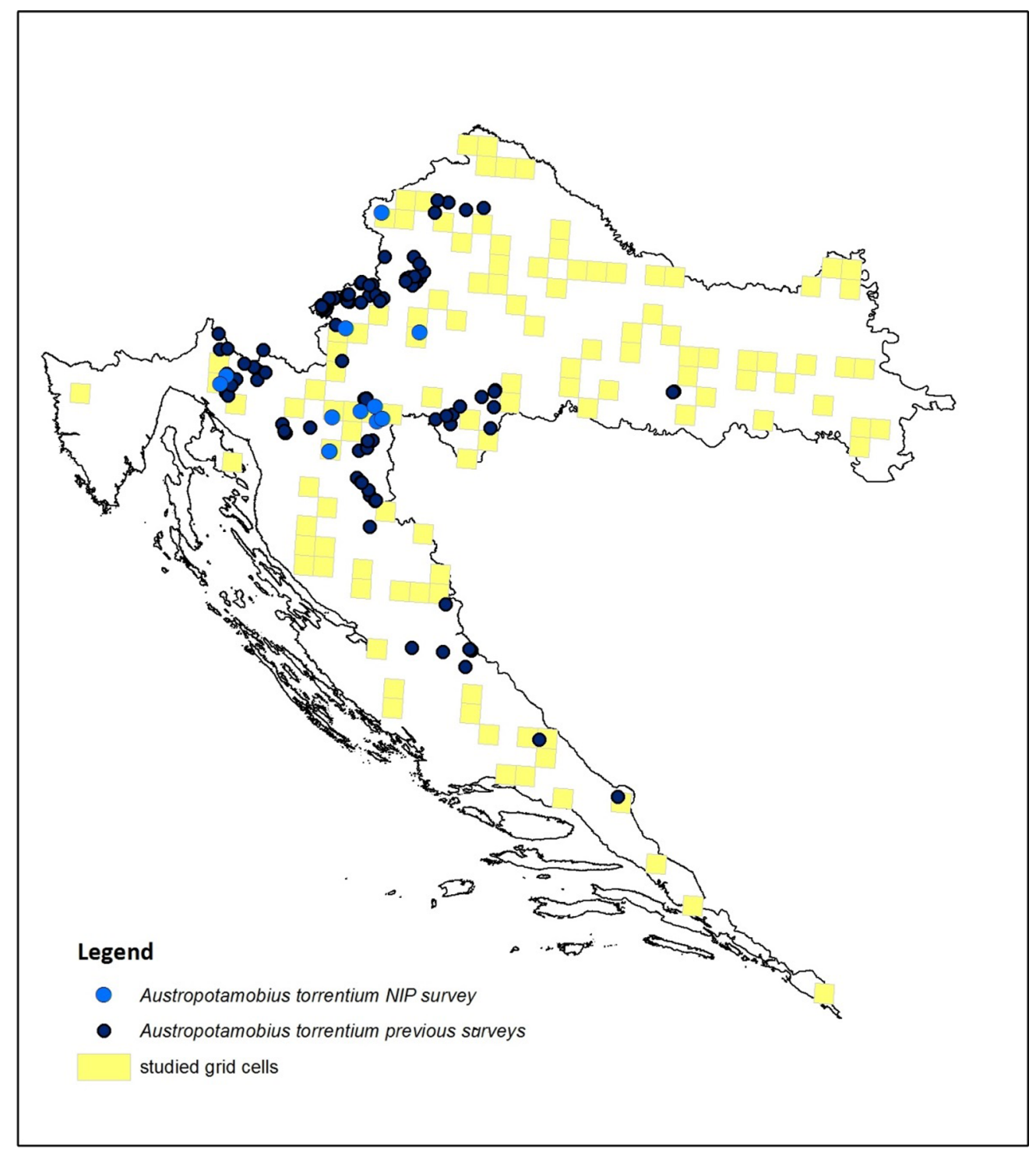

Fig. 6. Austropotamobius torrentium records within studied grid squares (light blue dots) and records from previous studies (dark blue dots).

purposes. If this negative trend continues, we can expect extinctions of $A$. pallipes from many areas in the Adriatic Sea drainage. At this point it should be also noted that in the southern parts of Croatia (waterbodies of the Adriatic Sea drainage), in spite of formal protection, crayfish are illegally caught for human consumption (Maguire et al., 2011), frequently translocated and introduced from nearby Bosnia and Herzegovina. Usually, local people have no proper knowledge on species affiliation and they are not aware of possible negative consequences of their actions, as documented during this survey by Hudina and Jelić (pers. comm.). Examples of such introductions would explain our unexpected records of $A$. astacus in the waterbodies of the Adriatic Sea drainage (Fig. 3), and presents a serious peril of introducing NICS and their diseases into sensitive freshwater ecosystems of the drainage (Diéguez-Uribeondo, 2006).

As for A. leptodactylus, the most robust European native species that shows some invasive characteristics (Holdich et al., 2009; Hudina et al., 2016; Perdikaris et al., 2017b), collected data indicated their spreading into new areas previously inhabited by $A$. astacus (Maguire et al., 2011), and at the same time their disappearance due to NICS dispersal (this study, Hudina et al., 2013, 2017; Rebrina et al., 2015). Since A. leptodactylus is known to be moderately resistant to the pathogen $A$. astaci (Kokko et al., 2012; Svoboda et al., 2012), we may expect its further slow-paced disappearance in contact zones with NICS, mainly due to competitive exclusions (Hudina et al., 2016), and further spreading and replacement of other ICS in continental Croatia.

It can be concluded that the current distributional pattern of ICS in Croatia still reflects their general historical distribution, in spite of the loss of many local populations. The disappearance of ICS populations is mainly due to various anthropogenic pressures on their habitats, as well as pronounced droughts or spreading of NICS. Existing ICS populations are frequently fragmented and isolated, which may lead to reduction of genetic diversity, and finally extinction due to inbreeding depression or some stochastic environmental 


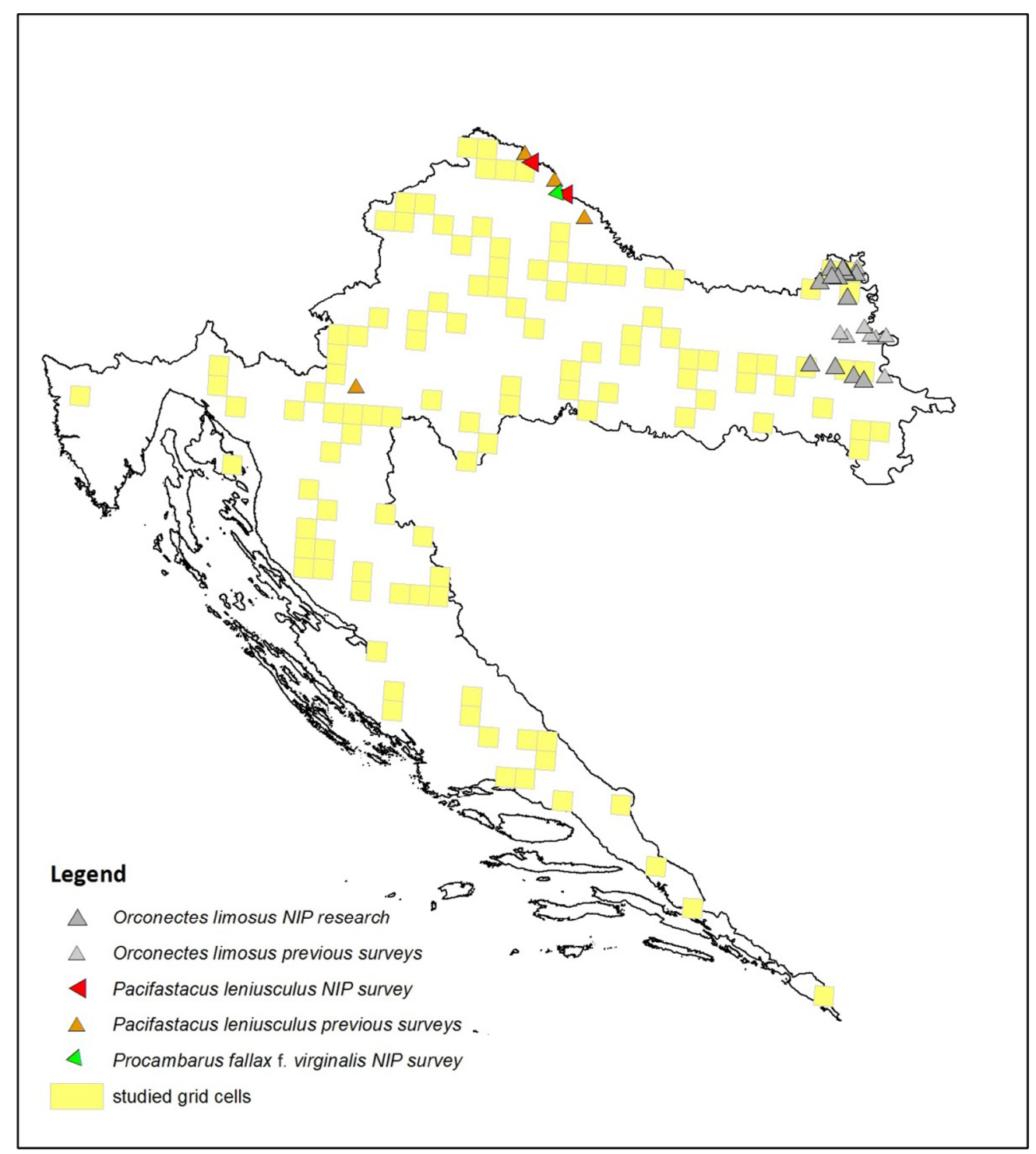

Fig. 7. Invasive crayfish species records within studied grid squares; Pacifastacus leniusculus (red triangles, localities from previous studies brown triangles), Orconectes limosus (dark grey triangles, localities from previous studies - light grey triangles) and Procambarus fallax f. virginalis (green triangle).

event (e.g., drought, flood). Further monitoring is essential to tack the rapid changes in ICS populations demonstrated in this investigation. Also, it is necessary to rise public awareness of negative impacts of NICS and importance of ICS preservation. In addition there is an urgent need for developing landscapelevel models to predict survivability chances of ICS populations, so that the best conservation strategies can be determined and applied as soon as possible to mitigate negative impacts of both NICS and anthropogenic influences.

Acknowledgements. This research was funded by the EU NIP. We would like to thank to G. Hudina, Z. Ivančan and I. Šarić for their assistance in the field. We are also grateful to A. P. Maguire for help with figure preparations, Prof. S. R. Gelder for helpful suggestions and English language editing, and the two reviewers for constructive criticism that helped us to improve original version of this manuscript.

\section{References}

Bohl E. 1999. Crayfish stock situation in Bavaria (Germany) attributes, threats and chances. Freshw Crayfish 12: 765-777.

Chucholl C, Schrimpf A. 2016. The decline of endangered stone crayfish (Austropotamobius torrentium) in southern Germany is related to the spread of invasive alien species and land-use change. Aquat Conserve Mar Freshw Ecosyst 26: 44-56.

Crandall KA, Buhay JE. 2008. Global diversity of crayfish (Astacidae, Cambaridae, and Parastacidae - Decapoda) in freshwater. Hydrobiologia 595: 295-301.

Diéguez-Uribeondo J. 2006. The dispersion of the Aphanomyces astaci-carrier Pacifastacus leniusculus by humans represents the main cause of disappearance of the indigenous crayfish Austropotamobius pallipes in Navarra. Bull Fr Pêche Piscic 1303: 380381.

Edgerton BF, Henttonen P, Jussila J, Mannonen A, Paasonen P, Taugbol T, Edsman L, Souty-Grosset C. 2004. Understanding the 
causes of disease in European freshwater crayfish. Conserv Bio 18: $1466-1474$

Edsman L, Füreder L, Gherardi F, Souty-Grosset C. 2010. Astacus astacus. In: IUCN 2010. IUCN Red List of Threatened Species. Version 2010. 04. www.iucnredlist.org (last consulted on: 2017/31/05).

Entz G. 1914. Über die Flusskrebse Ungarns. Mathematische und Naturwissenschaftliche Berichte aus Ungarn [1912] 30: 67-127.

Filipová L, Petrusek A, Matasová K, Delaunay C, Grandjean F. 2013. Prevalence of the crayfish plague pathogen Aphanomyces astaci in populations of the signal crayfish Pacifastacus leniusculus in France: evaluating the threat to native crayfish. PLOS ONE 8: e70157.

Fratini S, Zaccara S, Barbaresi S, et al. 2005. Phylogeography of the threatened crayfish (genus Austropotamobius) in Italy: implications for its taxonomy and conservation. Heredity 94: 108-118.

Füreder L, Oberkofler B, Hanel R, Machino Y. 2002. Freshwater crayfish in South Tyrol (Italy): distribution and protection measures of endangered Austropotamobius pallipes. Bull Fr Pêche Piscic 367: 651-662.

Füreder L, Edsman L, Holdich DM, et al. 2006. Indigenous crayfish habitat and threats. In Souty-Grosset C, Holdich DM, Noël P, Reynolds JD, Haffner P, eds. Paris: Atlas of Crayfish in Europe, Muséum national d' Histoire naturelle (Partimoines naturels, 64), pp. 25-47.

Füreder L, Gherardi F, Souty-Grosset C. 2010a. Austropotamobius torrentium. In: IUCN 2010. IUCN Red List of Threatened Species. Version 2010. 4. www.iucnredlist.org (last consulted on: 2017/31/ 05).

Füreder L, Gherardi F, Holdich D, Reynolds J, Sibley P, SoutyGrosset C. 2010b. Austropotamobius pallipes. In: IUCN 2010. IUCN Red List of Threatened Species. Version 2010. 4. www. iucnredlist.org (last consulted on: 2017/31/05).

Ghia D, Fea G, Sacchi R, et al. 2013. Modelling environmental niche for the endangered crayfish Austropotamobius pallies complex in northern and central Italy. Frewhw Crayfish 19: 189-195.

Giesen A. 2013. The genetic diversity of the native stone crayfish (Austropotamobius torrentium) and effects of habitat fragmentation on the population structure in canton Zurich, Switzerland: Diploma thesis Universität Koblenz - Landau, 38 p.

Gil-Sánchez JM, Alba-Tercedor J. 2006. The decline of the endangered populations of the native freshwater crayfish (Austropotamobius pallipes) in southern Spain: it is possible to avoid extinction? Hydrobiologia 559: 113-122.

Gottstein S, Hudina S, Lucić A, Maguire I, Ternjej I, Žganec K. 2011. Crveni popis rakova (Crustacea) slatkih i bočatih voda Hrvatske, Zagreb: Državni zavod za zaštitu prirode, 51 p. (Red list of freshwater and brackish Crustacea in Croatia; in Croatian).

Gouin N, Souty-Grosset C, Ropiquet A, Grandjean F. 2002. High dispersal ability of Austropotamobius pallipes revealed by microsatellite markers in a French brook. Bull Fr Pêche Piscic 367: 681-689.

Govedič M. 2017. First record of the spiny-cheek crayfish (Orconectes limosus) in Slovenia - $300 \mathrm{~km}$ upstream from its known distribution in the Drava River. Knowl Manag Aquat Ecosyt 418: 7.

Grandjean F, Gouin N, Souty-Grosset C, Diéguez-Uribeondo J. 2001. Drastic bottlenecks in the endangered crayfish species Austropotamobius pallipes in Spain and implications for its colonization history. Heredity 86: 431-438.

Holdich DM, Reynolds JD, Souty-Grosset C, Sibley PJ. 2009. A review of the ever increasing threat to European crayfish from nonindigenous crayfish species. Knowl Manag Aquat Ecosyst 394395: 11 .
Hudina S, Faller M, Lucić A, Klobučar G, Maguire I. 2009. Distribution and dispersal of two invasive crayfish species in the Drava River basin, Croatia. Knowl Manag Aquat Ecosyst 394-395: 9.

Hudina S, Žganec K, Lucić A, Trgovčić K, Maguire I. 2013. Recent invasion of the karstic river systems in Croatia through illegal introductions of the signal crayfish. Freshw Crayfish 19: 21-27.

Hudina S, Hock K, Radović A, et al. 2016. Species-specific differences in dynamics of agonistic interactions may contribute to the competitive advantage of the invasive signal crayfish (Pacifastacus leniusculus) over the native narrow-clawed crayfish (Astacus leptodactylus). Mar Freshw Behav Physiol 49: 147-157.

Hudina S, Kutleša, P, Trgovčević K, Duplić A. 2017. Dynamics of range expansion of the signal crayfish (Pacifastacus leniusculus) in a recently invaded region in Croatia. Aquat Invasions 12: 67-75.

Jelić M, Klobučar GIV, Grandjean F, et al. 2016. Insights into the molecular phylogeny and historical biogeography of the whiteclawed crayfish (Decapoda, Astacidae). Mol Phylogenet Evol 103: 26-40.

Jussila J, Maguire I, Kokko H, Makkonen J. 2016. Chaos and adaptation in the pathogen-host relationship in relation to the conservation The case of the crayfish plague and the noble crayfish. In: Kawai T, Faulkes Z, Scholtz G, eds. Freshwater Crayfish - A global overview, Boca Raton: Taylor and Francis, 246-275.

Karaman S. 1929. Die Potamobiiden Jugoslaviens. Glasnik zemaljskog muzeja u Bosni i Hercegovini XLI: 147-150 (The potamobiids of Yugoslavia, In German).

Karaman MS. 1961. Slatkovodni rakovi Jugoslavije. Publikacije stručnog udruženja za unapređenje slatkovodnog ribarstva Jugoslavije 3: 1-33. (Freshwater crayfish of Yugoslavia, in Serbain, with abstract in German).

Keller LF, Waller DM. 2002. Inbreeding effects in wild populations. Trends Ecol Evol 17: 230-241.

Klobučar G, Podnar M, Jelić M, et al. 2013. Role of the Dinaric Karst (western Balkans) in shaping the phylogeographic structure of the threatened crayfish Austropotamobius torrentium. Freshw Biol 58: $1089-1105$

Kokko H, Koistinen L, Harlioglu MM, Makkonen J, Aydın H, Jussila J. 2012. Recovering Turkish narrow clawed crayfish (Astacus leptodactylus) populations carry Aphanomyces astaci. Knowl Manag Aquat Ecosyst 404: 12.

Kouba A, Petrusek A, Kozák P. 2014. Continental-wide distribution of crayfish species in Europe: update and maps. Knowl Manag Aquat Ecosyst 413: 05.

Kozák P. 2015. Crayfish conservation. In Kozák P, Ďuriš Z, Petrusek A, Buřič M, Horká I, Kouba A, Kozubíková-Balzarová E, Policar T, eds. Crayfish biology and culture. Vodnany (Czech Republic): University of Southern Bohemia in České Budějovice, pp. 393 403.

Ludányi M, Peeters ETHME, Kiss B, Roessink I. 2016. Distribution of crayfish species in Hungarian waters. Global Ecol Conserv 8: 254-262.

Maguire I, Gottstein-Matočec S. 2004. The distribution pattern of freshwater crayfish in Croatia. Crustaceana 77: 25-49.

Maguire I, Klobučar GIV. 2003. Appearance of Orconectes limosus in Croatia. Crayfish News 25: 3.

Maguire I, Erben R, Klobučar GIV, Lajtner J. 2002. A year cycle of Austropotamobius torrentium (Schrank) in streams on Medvednica mountain (Croatia). Bull Fr Pêche Piscic 367: 943-957.

Maguire I, Klobučar G, Marčić Z, Zanella D. 2008. The first record of Pacifastacus leniusculus in Croatia. Crayfish News 30: 4.

Maguire I, Jelić M, Klobučar G. 2011. Update on the distribution of freshwater crayfish in Croatia. Knowl Manag Aquat Ecosyst 401: 31. 
Maguire I, Jelić M, Klobučar G, Delpy M, Delaunay C, Grandjean F. 2016. Prevalence of the pathogen Aphanomyces astaci in freshwater crayfish populations in Croatia. Dis Aquat Organ 118: 45-53.

Maguire I, Marn N, Klobučar G. 2017. Morphological evidence for hidden diversity in the threatened stone crayfish Austropotamobius torrentium (Schrank, 1803) (Decapoda: Astacoidea: Astacidae) in Croatia. J Crustacean Biol 37: 7-15.

NN 80/13 (Official Gazette 80/13) Law of Nature Protection.

NN 88/14 (Official Gazette 88/14) Ordinance on the habitat types, habitat map and threatened and rare habitat types.

Pârvulescu L, Pacioglu O, Hamchevici C. 2011. The assessment of the habitat and water quality requirements of the stone crayfish (Austropotamobius torrentium) and noble crayfish (Astacus astacus) species in the rivers from the Anina Mountains (SW Romania). Knowl Managt Aquatic Ecosyst 401: 03.

Perdikaris C, Georgiadis C. 2017a. Co-occurrence of narrow-clawed crayfish (Astacus leptodactylussensu lato) and noble crayfish (Astacus astacus L.) in the southwestern Balkans: the case of Lake Pamvotida (NW Greece). North-West J. Zool 13: 18-26.

Perdikaris C, Konstantinidis E, Georgiadis C. Kouba A. 2017b. Freshwater crayfish distribution update and maps for Greece: combining literature and citizen-science data. Knowl Manag Aquat Ecosyst 418: 51.

Policar T, Kozák P. 2015. Production and culture of crayfish. In: Kozák P, Ďuriš Z, Petrusek A, Buřič M, Horká I, Kouba A, Kozubíková-Balzarová E, Policar T, eds. Crayfish Biology and Culture. Vodnany (Czech Republic): University of South Bohemia in České Budějovice, Faculty of Fisheries and Protection of Waters, pp. 293-363.

Rebrina F, Skejo J, Lucić A, Hudina S. 2015. Trait variability of the signal crayfish (Pacifastacus leniusculus) in a recently invaded region reflects potential benefits and trade-offs during dispersal. Aquat Invasions 10: 41-50.

Rezinciuc S, Sandoval-Sierra JV, Oidtmann B, Diéguez-Uribeondo J. 2015. The biology of crayfish plague pathogen Aphanomyces astaci: current answers to most frequent questions. In: Kawai T,
Faulkes Z, Scholtz G, eds. Freshwater Crayfish - A Global Overview, Boca Raton: Taylor and Francis, 182-204.

Rosewarne PJ, Mortimer RJG, Dunn AM. 2017. Habitat use by the endangered white-clawed crayfish Austropotamobius species complex: a systematic review. Knowl Manag Aquat Ecosyst 418: 4.

Samardžić M, Lucić A, Maguire I, Hudina S. 2014. The first record of the marbled crayfish (Procambarus fallax (Hagen, 1870) $f$. virginalis) in Croatia. Crayfish News 36: 4.

Schrimpf A, Theissinger K, Dahlem J, et al. 2014. Phylogeography of noble crayfish (Astacus astacus) reveals multiple refugia. Freshw Biol 59: 761-776.

Simić V, Petrović A, Rajković M, Paunović M. 2008. Crayfish of Serbia and Montenegro - the population status and the level of endangerment. Crustaceana 81: 1153-1176.

Souty-Grosset C. 2005. Introduction: the EU-network CRAYNET impacts on fundamental questions. Bull Fr Pêche Piscic 376-377: 495-503.

Souty-Grosset C, Holdich DM, Noël PY, Reynolds J, Haffner P. 2006. Atlas of crayfish in Europe, Paris: Muséum National d'Histoire Naturelle, $187 \mathrm{p}$.

Svoboda J, Kozubíková E, Kozák P, et al. 2012. PCR detection of the crayfish plague pathogen in narrow-clawed crayfish inhabiting Lake Egirdir in Turkey. Dis Aquat Organ 98: 255-259.

Twardochleb LA, Olden JD, Larson ER. 2013. A global meta-analysis of the ecological impacts of nonnative crayfish. Freshw Sci 32: $1367-1382$.

Weinländer M, Bou-Vinals A, Füreder L. 2014. Landscape analyses offer a promising tool for manageing native and alien crayfish species. Freshw Crayfish 20: 27-40.

Westman K, Pursiainen M, Vilkman R. 1978. A new folding trap model which prevents crayfish from escaping. Freshw Crayfish 4: 235-242.

Westman K, Savolainen R, Julkunen M. 2002. Replacement of the native crayfish Astacus astacus by the introduced species Pacifastacus leniusculus in a small enclosed Finnish lake: a 30 year study. Ecography 25: 53-73.

Cite this article as: Maguire I, Klobučar G, Žganec K, Jelić M, Lucić A, Hudina S. 2018. Recent changes in distribution pattern of freshwater crayfish in Croatia - threats and perspectives. Knowl. Manag. Aquat. Ecosyst., 419, 2. 